\title{
酛 New Disease Reports \\ First report of the Zymoseptoria tritici teleomorph stage causing septoria leaf blotch of wheat in Algeria
}

\author{
W. Harrat ${ }^{1,2}$, H. Meamiche Neddaf ${ }^{1,2} *$, A. Keddad ${ }^{1}$ and Z. Bouznad ${ }^{1}$ \\ ${ }^{1}$ Ecole Nationale Supérieure d'Agronomie, Laboratoire de Phytopathologie et de Biologie Moléculaire, Avenue Hassen Badi, \\ El Harrach, Algeria; ${ }^{2}$ Institut National de Recherche Agronomique d'Algérie, 2 rue les Frères Oudek, El Harrach, Algeria
}

*E-mail: meamiche.hayet@gmail.com

Received: 04 May 2017. Published: 06 Jun 2017. Keywords: ascospores, durum wheat, pseudothecia, sexual reproduction

\begin{abstract}
Durum wheat (Triticum durum) is one of the most important cereal crops in Algeria with an annual production of approximately 1.3 million tonnes in 2015-2016. Septoria leaf blotch caused by Zymoseptoria tritici (syn. Mycosphaerella graminicola) is considered to be one of the major diseases affecting both durum and bread wheat in Algeria. Algerian Z. tritici populations undergo frequent sexual reproduction mirrored by cooccurrence of both mating types (Allioui $e t$ al., 2014; Meamiche Neddaf $e t$ al., 2017). Pseudothecia have been obtained under controlled conditions (Ayad et al., 2014), however the natural occurrence of the teleomorph stage has never been reported in the country.
\end{abstract}

In November 2015, wheat stubble from naturally infected wheat fields in two different growing regions in Algeria (Algiers and Constantine) was sampled and examined for the presence of pseudothecia. Pseudothecia were observed using a stereomicroscope (Fig. 1). Five to ten pseudothecia were picked off with a needle, placed on a microscope slide in a drop of water, crushed and identified on the basis of their morphological characteristics (Fig. 2). Pseudothecia were dark brown, 68-117 $\mu \mathrm{m}$ in diameter, asci were hyaline, bitunicate, obpyriform, 33.5-48 $\times$ 10.5-33 $\mu \mathrm{m}$ and contained eight ascospores per ascus (Fig. 3). Ascospores were twocelled, hyaline, $9-14 \times 2-3 \mu \mathrm{m}$.

Leaf samples bearing abundant fruiting bodies were selected and ascospores trapped using the inverted Petri dish method (Kema et al., 1996). Ascospore-derived isolates were sub-cultured on potato dextrose agar, incubated at $18^{\circ} \mathrm{C}$ during five days in the dark prior to undertaking a pathogenicity test. Young wheat plants $\mathrm{cv}$. Hoggar were inoculated by spraying a spore suspension $\left(5 \times 10^{6}\right.$ spores $\left./ \mathrm{ml}\right)$ supplemented with two drops of Tween 20 per $40 \mathrm{ml}$, placed in moistened plastic bags for $72 \mathrm{~h}$ and kept under greenhouse conditions. Control plants were sprayed with sterile water. After $14 \pm 2$ days typical necrotic blotches with pycnidia were observed (Fig. 4). The pathogen was consistently reisolated from lesions. No symptoms were observed on the control plants inoculated with sterile water.

This is the first report of the Zymoseptoria tritici teleomorph causing septoria leaf blotch on wheat in Algeria. Regular sexual reproduction generates new genotypes able to overcome host resistance (Cowger \& Mundt, 2002) and adapt to other selective pressures, such as those generated by fungicide application.

\section{Acknowledgements}

The authors would like to thank Gert Kema for his support and Frederic Suffert for his technical assistance. W. Harrat and H. Meamiche Neddaf contributed equally to this work.

\section{References}

Allioui N, Siah A, Brinis L, Reignault P, Halama P, 2014. Mating type distribution provides evidence for sexual reproduction of Mycosphaerella graminicola in Algeria. Canadian Journal of Plant Pathology 36, 475-481. http://dx.doi.org/10.1080/07060661.2014.964777

Ayad D, Sayoud R, Benbelkacem K, Bouznad Z, 2014. La tache septorienne du blé: Première signalisation de la présence en Algérie des deux mating types du téleomorphe Mycosphaerella graminicola (Fuckel) Schröter, (anamorphe: Septoria tritici Rob ex Desm.) et diversité phénotypique de l'agent pathogène. Nature et Technologie 11, 34-45.

Cowger C, Mundt CC, 2002. Aggressiveness of Mycosphaerella graminicola isolates from susceptible and partially resistant wheat cultivars. Ecology and Population Biology 92, 624-630. http://dx.doi.org/10.1094/PHYTO.2002.92.6.624

Kema GHJ, Verstappen ECP, Todorova M, Waalwijk C, 1996. Successful crosses and molecular tetrad and progeny analysis demonstrate heterothallism in Mycosphaerella graminicola. Current Genetics 30, 251-258. http://dx.doi.org/10.1007/s002940050129

Meamiche Neddaf H, Aouini L, Bouznad Z, Kema GHJ, 2017. Equal distribution of mating type alleles and the presence of strobilurin resistance in Algerian Zymoseptoria tritici field populations. Plant Disease 101, 1-6. http://dx.doi.org/10.1094/PDIS-03-16-0298-RE

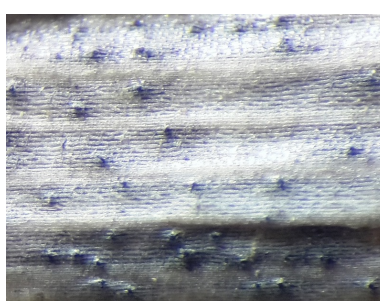

Figure 1

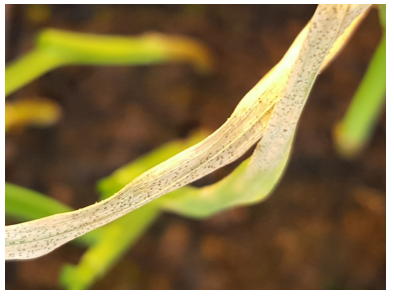

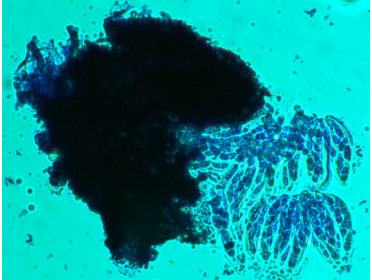

Figure 2

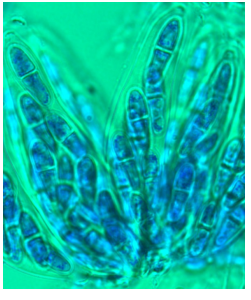

Figure 3

Figure 4

To cite this report: Harrat W, Meamiche Neddaf H, Keddad A, Bouznad Z, 2017. First report of the Zymoseptoria tritici teleomorph stage causing septoria leaf blotch of wheat in Algeria. New Disease Reports 35, 30. http://dx.doi.org/10.5197/j.2044-0588.2017.035.030

(c) 2017 The Authors

This report was published on-line at www.ndrs.org.uk where high quality versions of the figures can be found. 